Syntax Literate: Jurnal Ilmiah Indonesia p-ISSN: 2541-0849

e-ISSN: 2548-1398

Vol.6, No.10, Oktober 2021

\title{
ANALISIS FAKTOR-FAKTOR YANG MEMPENGARUHI KESADARAN DAN KEPATUHAN MASYARAKAT DALAM MEMATUHI PROTOKOL KESEHATAN DI ERA COVID-19
}

\author{
Rizki Rahmah Fauzia, Retno Tresno Sundari, Zaenal Arifin \\ Prodi S1 Farmasi, Prodi Pendidikan Apoteker STF YPIB Cirebon, Jawa Barat, \\ Indonesia \\ Email: kikirahmah88@gmail.com, retnotresno69@gmail.com, aaenal633@gmail.com
}

\begin{abstract}
Abstrak
Menggunakan masker, mencuci tangan dan menjaga jarak di era COVID-19 merupakan salah satu bentuk kesadaran dan kepatuhan dalam menjalankan protokol kesehatan. Penelitian ini bertujuan untuk mengetahui kesadaran dan kepatuhan masyarakat dalam mematuhi protokol kesehatan di era COVID-19 dan untuk mengetahui faktor apa saja yang mempengaruhi kesadaran dan kepatuhan masyarakat dalam mematuhi prtotkol kesehatan di era COVID-19. Penelitian ini merupakan deskriptif analitik dengan instrumen penelitian berupa wawancara dan kuesioner. Responden berjumlah 100 orang yang berusia 18-50 tahun. Adapun butir soal didalam kuesioner dilakukan uji validitas dan uji reliabilitas. Hasil penelitian berupa persentase dari faktor-faktor yang mempengaruhi kesadaran dan kepatuhan dalam mematuhi protokol kesehatan. Kesadaran dan kepatuhan masyarakat dalam mematuhi protokol kesehatan di era COVID-19 adalah sangat baik dengan persentase masyarakat yang mengetahui anjuran dari pemerintah tentang protokol kesehatan sebesar $100 \%$, dan masyarakat yang sudah sadar dan mengerti mengenai protokol kesehatan sebesar 97\%. Faktor-faktor yang mempengaruhi kesadaran dan kepatuhan masyarakat dalam mematuhi protokol kesehatan di era COVID-19 yaitu masyarakat yang sudah menggunakan masker saat keluar rumah sebesar 95\%, masyarakat yang sudah patuh dengan pemerintah dengan melakukan mencuci tangan setelah keluar dari rumah sebesar 98\%, masyarakat yang sudah patuh dengan anjuran pemerintah dengan selalu menjaga jarak saat berada dikerumunan sebesar 94\%, masyarakat yang sudah mengetahui apabila melanggar protokol kesehatan dapat dikenakan sanksi sebesar $90 \%$.
\end{abstract}

Kata Kunci: kesadaran; kepatuhan; protokol kesehatan; COVID-19

\section{Abstract:}

Using masks, washing hands and maintaining distance in the COVID-19 era are forms of awareness and compliance in implementing health protocols. This study aims to determine public awareness and compliance in complying with health protocols in the COVID-19 era. To find out what factors affect public awareness and compliance in complying with health protocols in the COVID-19 era. This research is an analytic descriptive with research instruments in the form of interviews and questionnaires. Respondents amounted to 100 people aged 18-50 
years. The items in the questionnaire were tested for validity and reliability tests. The results of the study are the percentage of factors that affect awareness and compliance in complying with health protocols. Public awareness and compliance in complying with health protocols in the COVID-19 era is very good with the percentage of people who know the recommendations from the government about health protocols by $100 \%$, and people who are aware and understand about health protocols by 97\%. Factors that affect public awareness and compliance in complying with health protocols in the COVID-19 era are $95 \%$ of people who have used masks when leaving the house, $98 \%$ of people who have obeyed the government by washing their hands after leaving the house, and $98 \%$ of people who have complied with the government. $94 \%$ of people who have complied with government recommendations by always keeping their distance when in crowds, people who already know if they violate health protocols can be subject to sanctions of $90 \%$.

Keywords: awareness; compliance; health protocol; COVID-19

Received: 2021-09-20; Accepted: 2021-10-05; Published: 2021-10-20

\section{Pendahuluan}

Negara Indonesia kita ini tengah menghadapi ancaman situasi menegangkan berupa penyakit berbahaya yang bermulanya ditemukan COVID-19 (Coronavirus Disease) pada manusia di kota Wuhan, tepatnya terletak di Hubei, China bulan Desember tahun 2019. Diduga virus ini mirip MERS dan SARS dengan gejalanya yaitu demam lebih dari 38oC, sesak nafas, pilek, batuk dan sindrom pernafasan akut bahkan dapat menyebabkan seseorang meninggal dunia (K, 2020).

Dalam mencegah penyebaran COVID-19, ada beberapa protokol kesehatan yang dapat dilaksanakan baik secara individu ataupun masyarakat, meliputi (3M) mencuci tangan, memakai masker dan menjaga jarak. Mencuci tangan merupakan metode esensial dalam mencegah transmisi COVID-19. Sebuah penelitian mengungkapkan mencuci tangan yang efektif melibatkan metode WHO menggunakan air dan sabun selama 40-60 detik. Selain mencuci tangan, penggunaan masker berperan dalam pencegahan transmisi COVID-19. Untuk dapat mengurangi bahkan memutus mata rantai infeksi COVID-19, seseorang harus menjaga jarak aman dengan manusia lainnya minimal 1 meter (Esposito, Principi, Leung, \& Migliori, 2020).

Adapun peraturan perundang-undangan yang telah dikeluarkan oleh pemerintah terkait penyakit tersebut yaitu UU Nomor 4 Tahun 1984 tentang Wabah Penyakit Menular, UU Nomor 6 Tahun 2018 tentang Kekarantinaan Kesehatan, Peraturan Pemerintah Nomor 21 Tahun 2020 tentang Pembatasan Sosial Berskala Besar (PSBB), dan Peraturan Menteri Kesehatan (Permenkes) RI nomor 9 tahun 2020 tentang Pedoman Pembatasan Sosial Berskala Besar dalam rangka percepatan penanganan corona virus disease 2019 (COVID-19).

Salah satu peraturan tersebut mengatur tentang bagaimana protokol kesehatan harus dilakukan oleh masyarakat untuk mencegah penyebaran virus COVID-19. 
Tentunya implementasi protokol kesehatan tidak akan maksimal apabila tidak didukung dengan partisipasi masyarakat, sehingga diperlukan suatu usaha untuk meningkatkan kesadaran dan kepatuhan masyarakat dalam mendukung berjalannya protokol kesehatan. Dan tentunya usaha yang diperlukan untuk mencegah penyebaran COVID19 ini harus kita ketahui dulu apakah faktor-faktor yang mempengaruhi kesadaran dan kepatuhan masyarakat dalam mematuhi protokol Kesehatan (Ginting, Kaban, \& Ginting, 2021).

Sudah ada penelitian yang dilakukan oleh (Afrianti \& Rahmiati, 2021b) bahwa faktor yang mempengaruhi kepatuhan masyarakat terhadap protokol kesehatan yaitu usia, pendidikan, pengetahuan, sikap, dan motivasi. Untuk mencapai suatu kepatuhan perlu adanya suatu kesadaran dalam diri masyarakat untuk mereka bisa patuh sehingga dilakukanlah pembaharuan dalam penelitian ini yaitu untuk mengetahui faktor-faktor apa saja yang mempengaruhi kesadaran dan kepatuhan masyarakat dalam mematuhi protokol kesehatan.

\section{Metode Penelitian}

Sampel yang digunakan adalah sebanyak 100 warga Dusun Karangsari yang terdiri dari 2 RW dan 6 RT dengan kriteria inklusi yaitu warga yang berusia 18-50 tahun dan bersedia untuk mengisi kuesioner maupun wawancara. Penelitian ini adalah penelitian non eksperimental yang bersifat deskriptif kuantitatif (Rukajat, 2018). Adapun instrument penelitian yang digunakan yaitu kuesioner dan wawancara. Langkah Penelitian yang dilakukan yaitu uji validitas dan uji reliabilitas kuesioner, perizinan, pengumpulan data, pengolahan data, analisis data dan kesimpulan.

\section{Uji Validitas dan Reliabilitas Data}

Uji validitas dan reliabilitas ini dilakukan pada 30 responden dengan menggunakan face falidity untuk menguji validitas yang digunakan dan uji reliabilitas menggunakan metode split half-alpha dengan program SPSS. Syarat minimum untuk dianggap suatu butir instrument valid adalah nilai indeks valid adalah nilai indeks validitasnya $\geq 0,3$. Kriteria suatu instrument dikatakan reliabel bila koefisien reliabilitas 0,70 . Keputusan yang digunakan untuk uji reliabilitas ini adalah sebagai berikut:

1) Jika nilai $\geq 0,70$ maka seluruh butir pertanyaan dinyatakan reliabel, yang artinya instrument layak dan dapat digunakan.

2) Jika nilai $\leq 0,70$ maka seluruh butir pertanyaan dinyatakan tidak reliabel, yang artinya instrument tidak layak dan tidak dapat digunakan (Mudhar, 2017).

\section{Hasil dan Pembahasan}

\section{A. Hasil Uji Validitas Data}

Uji validitas bertujuan untuk mengetahui kevalidan atau kesesuaian kuesioner yang digunakan oleh peneliti dalam mengukur dan memperoleh data penelitian dari para responden. Dasar pengambilan uji validitas yaitu jika nilai $r$ hitung lebih besar 
dari nilai $r$ tabel maka dinyatakan valid, apabila nilai $r$ hitung lebih kecil dari nilai $r$ tabel maka dinyatakan tidak valid.

Berdasarkan hasil dari uji validitas bahwa semua instrument sebanyak 25 pertanyaan dengan jumlah sampel 30 memiliki nilai $r$ hitung lebih besar daripada $r$ tabel (0.316), sehingga dapat dikatakan bahwa semua instrumen pertanyaan dinyatakan valid.

\section{B. Hasil Uji Reliabilitas}

Dari nilai uji reliabilitas didapatkan semua nilai instrumen dari pertanyaan nomor 1 sampai nomor 25 semuanya menghasilkan nilai Alpha Cronbach's lebih dari 0.70 yaitu 0.984. Sehingga dapat disimpulkan bahwa semua instrumen pertanyaan ini reliabel.

Tabel 1

Hasil Uji Reliabilitas

\begin{tabular}{|c|c|c|c|c|}
\hline \multicolumn{5}{|c|}{ Item-Total Statistics } \\
\hline & $\begin{array}{l}\text { Scale Mean if } \\
\text { Item Deleted }\end{array}$ & $\begin{array}{l}\text { Scale Variance } \\
\text { if Item Deleted }\end{array}$ & $\begin{array}{c}\text { Corrected Item- } \\
\text { Total } \\
\text { Correlation }\end{array}$ & $\begin{array}{c}\text { Cronbach's } \\
\text { Alpha if Item } \\
\text { Deleted }\end{array}$ \\
\hline $\mathrm{X} 1$ & 18.63 & 72.240 & .997 & .983 \\
\hline $\mathrm{X} 2$ & 18.63 & 72.240 & .997 & .983 \\
\hline $\mathrm{X} 3$ & 18.63 & 72.240 & .997 & .983 \\
\hline $\mathrm{X} 4$ & 18.70 & 72.700 & .808 & .984 \\
\hline $\mathrm{X} 5$ & 18.63 & 72.240 & .997 & .983 \\
\hline X6 & 18.87 & 74.051 & .526 & .986 \\
\hline $\mathrm{X} 7$ & 18.70 & 72.838 & .788 & .984 \\
\hline $\mathrm{X} 8$ & 18.67 & 72.506 & .886 & .983 \\
\hline $\mathrm{X} 9$ & 18.67 & 72.575 & .876 & .983 \\
\hline $\mathrm{X} 10$ & 18.70 & 72.631 & .817 & .984 \\
\hline $\mathrm{X} 11$ & 18.77 & 73.289 & .665 & .985 \\
\hline $\mathrm{X} 12$ & 18.63 & 72.240 & .997 & .983 \\
\hline $\mathrm{X} 13$ & 18.70 & 72.838 & .788 & .984 \\
\hline $\mathrm{X} 14$ & 18.70 & 72.838 & .788 & .984 \\
\hline $\mathrm{X} 15$ & 18.67 & 72.575 & .876 & .983 \\
\hline $\mathrm{X} 16$ & 18.63 & 72.240 & .997 & .983 \\
\hline $\mathrm{X} 17$ & 18.67 & 72.575 & .876 & .983 \\
\hline $\mathrm{X} 18$ & 18.67 & 72.437 & .896 & .983 \\
\hline X19 & 18.73 & 73.099 & .716 & .984 \\
\hline $\mathrm{X} 20$ & 18.87 & 73.982 & .534 & .986 \\
\hline $\mathrm{X} 21$ & 18.63 & 72.240 & .997 & .983 \\
\hline $\mathrm{X} 22$ & 18.67 & 72.506 & .886 & .983 \\
\hline $\mathrm{X} 23$ & 18.67 & 72.506 & .886 & .983 \\
\hline X24 & 18.67 & 72.575 & .876 & .983 \\
\hline X25 & 18.70 & 72.769 & .798 & .984 \\
\hline
\end{tabular}

\begin{tabular}{ll}
\hline \multicolumn{2}{c}{ Reability Statistics } \\
\hline $\begin{array}{l}\text { Cronbach's } \\
\text { Alpha }\end{array}$ & N of Items \\
\hline .984 & 25 \\
\hline
\end{tabular}

\section{Karakteristik Demografi Responden}

1. Persentase Usia 


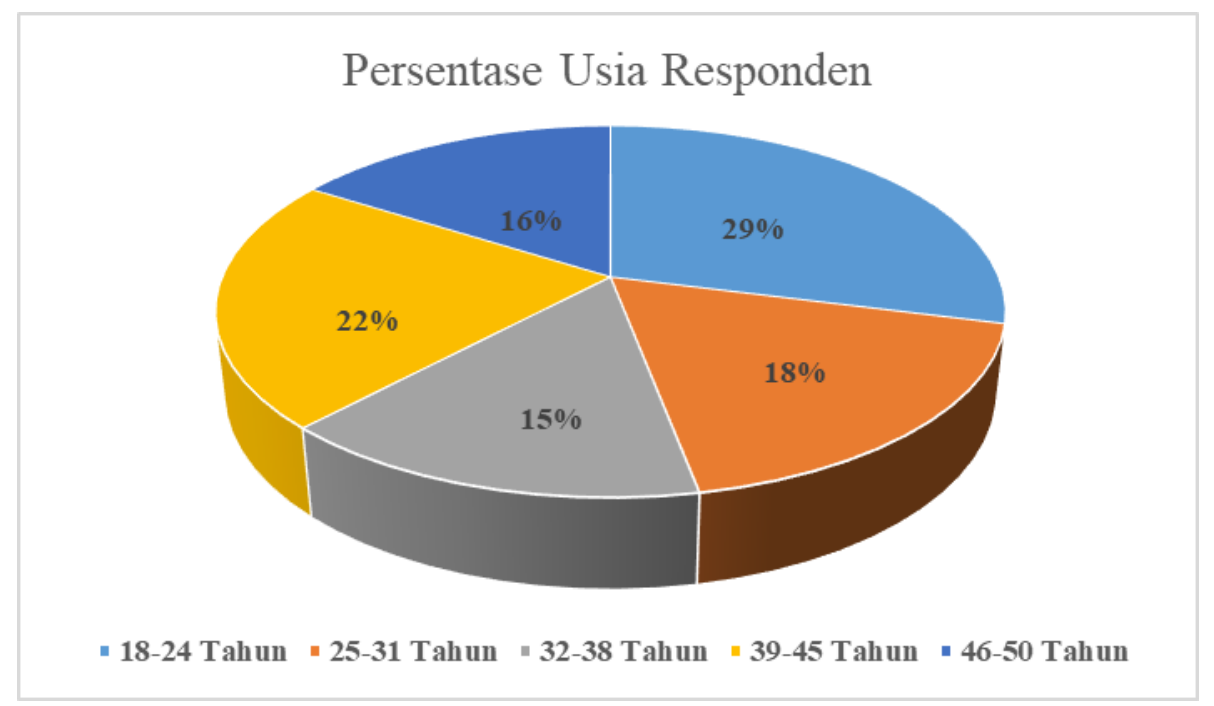

2. Persentase Jenis Kelamin

Tabel 2

Persentase jenis kelamin

\begin{tabular}{cccc}
\hline No. & Jenis Kelamin & Jumlah & Persentase (\%) \\
\hline 1 & Laki-laki & 44 Orang & $44 \%$ \\
\hline 2 & Perempuan & 56 Orang & $56 \%$ \\
\hline
\end{tabular}

3. Persentase Pekerjaan

\section{Persentase Jenis Pekerjaan Responden}

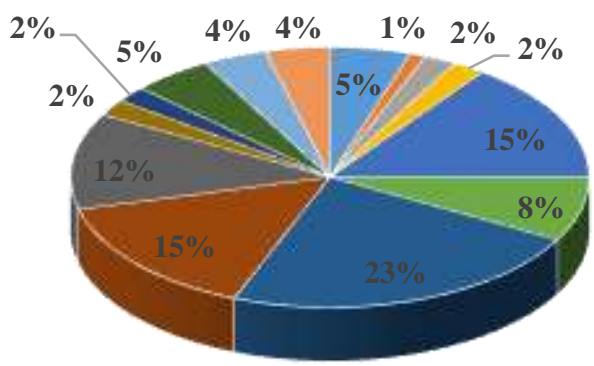

$\begin{array}{llll}\text { " Guru } & \text { " Dosen } & \text { " Asisten Dosen } & \text { " Asisten Apoteker } \\ \text { - Mahasiswa } & \text { " Wiraswasta } & \text { - Ibu Rumah Tangga } \\ \text { - Wirausaha } & \text { - Belum Bekerja } & \text { - Bidan } \\ \text { " Buruh } & \text { " Tukang Bangunan } & & \text { - Karyawan Swasta } \\ & & \end{array}$

4. Persentase Pendidikan Terakhir 


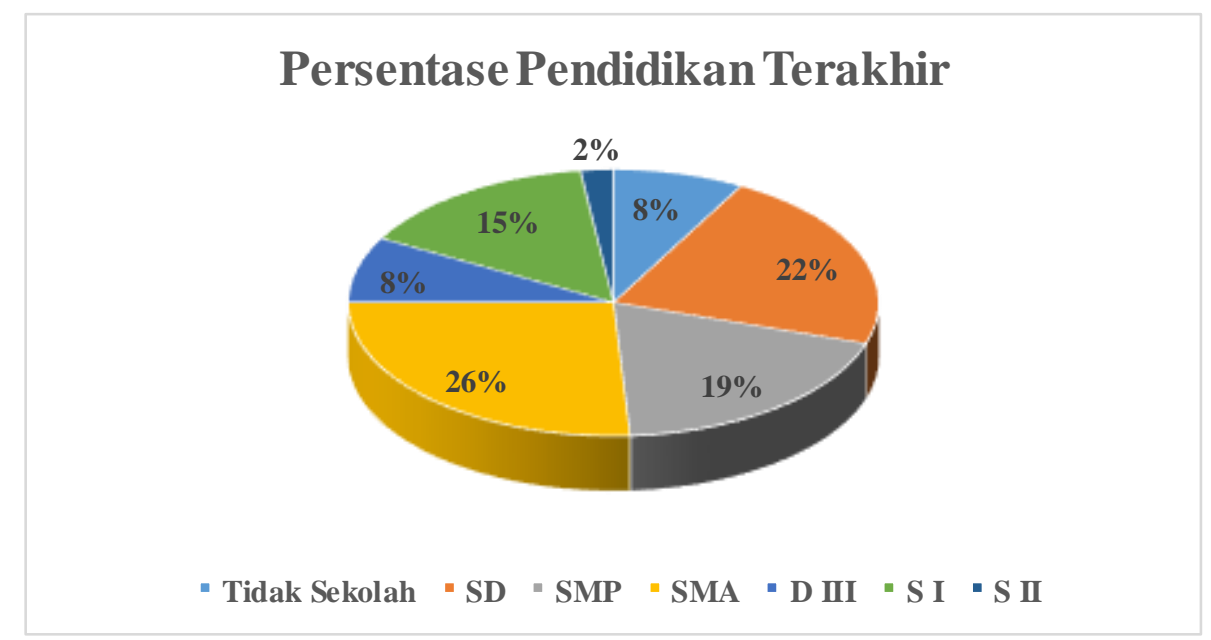

5. Persentase Komunikasi yang Didapatkan Responden

Tabel 3

Persentase Komunikasi yang Didapatkan Responden

\begin{tabular}{llll}
\hline No. & Penyuluhan Kepada Masyarakat & Jumlah & Persentase (\%) \\
\hline 1 & Ada & 74 & $74 \%$ \\
\hline 2 & Tidak Ada & 26 & $26 \%$ \\
\hline
\end{tabular}

\section{Analisis Kesadaran Masyarakat}

Kesadaran berasal dari kata sadar, yang berarti insaf, merasa, tahu atau mengerti (Kemendikbud, 2016). Sedangkan menurut (Soekanto \& Pengantar, 1982) kesadaran adalah nilai-nilai yang terdapat di dalam diri manusia. Berdasarkan hasil responden di Dusun Karangsari yang sudah menyadari betapa bahayanya penyakit ini sebesar $98 \%$, itu artinya masyarakat benar-benar sadar bahwa memang penyakit COVID-19 ini sangat berbahaya. Sedangkan kepercayaan masyarakat akan adanya COVID-19 yaitu sebesar 97\%, ini menandakan bahwa masyarakat sadar dan percaya terhadap pandemi COVID-19.

Selain itu masyarakat yang sudah mengerti dan memahami protokol kesehatan sebesar 97\%, dengan melihat bahwa sebagian besar masyarakat memiliki stok masker dan hand sanitizer di rumah dan hal ini menandakan bahwa masyarakat sudah sadar dan mengerti dengan menerapkan protokol kesehatan berupa memakai masker, mencuci tangan dan menjaga jarak (3M). Ini menandakan bahwa masyarakat sudah sadar dengan aturan-aturan yang diberikan oleh pemerintah. Sehingga dapat disimpulkan bahwa faktor-faktor yang mempengaruhi kesadaran responden di Dusun Karangsari adalah faktor pengetahuan berupa mengetahui bahaya penyakit, persepsi dan sikap yaitu kepercayaan terhadap COVID-19 dan pengetahuan protokol kesehatan.

\section{E. Analisis Kepatuhan Masyarakat}

(Albery \& Munafo, 2011) menyatakan bahwa kepatuhan mengacu kepada perilaku seorang individu sesuai dengan tindakan yang dianjurkan atau nasehat yang 
diusulkan oleh seorang praktisi kesehatan atau informasi yang diperoleh dari suatu sumber informasi lainnya. Dan Hal tersebut sejalan dengan hasil penelitian ini karena masyarakat yg mendapatkan komunikasi/informasi berupa penyuluhan tentang COVID-19 dan protocol kesehatan sebanyak 74\%. Hasil penelitian juga sejalan dengan (Sulistyaningtyas, Jaelani, \& Suryani, 2020) bahwa pengetahuan yang baik dipengaruhi oleh penerimaan terhadap suatu informasi yang beredar di masyarakat tentang COVID-19 melalui media yang efektif. Tentunya adanya informasi ataupun komunikasi yang dilakukan kepada masyarakat akan memberikan pengetahuan yang berdampak pada kesadaran dan kepatuhan masyarakat itu sendiri

Adapun media komunikasi yang digunakan oleh masyarakat yaitu adanya penyuluhan dari pemerintah secara langsung, melalui media cetak, sosial, elektronik dan melalui orang terdekat. Menurut (Aulia, 2021) faktor yang mempengaruhi kepatuhan seseorang berupa pengetahuan, motivasi, dan dukungan keluarga. Sehingga dalam hal ini adanya komunikasi dan motivasi dari orang terdekat merupakan salah satu faktor yang mempengaruhi kesadaran dan kepatuhan masyarakat.

Kesadaran hukum berkaitan dengan kepatuhan hukum, hal yang membedakannya yaitu dalam kepatuhan hukum ada rasa takut akan sanksi (Rosana, 2014). Kesadaran ataupun kepatuhan masyarakat menurut Sukanto (2007) dipengaruhi oleh faktor umur, pendidikan dan pekerjaan, ekonomi serta komunikasi. Sedangkan menurut (Afrianti \& Rahmiati, 2021a) ada lima faktor yang mempengaruhi kepatuhan terhadap protokol kesehatan COVID-19 yaitu usia, pendidikan, pengetahuan, sikap dan motivasi.

Berdasarkan hasil kuesioner yang didapatkan bahwa Responden di Dusun Karangsari memiliki kepatuhan yang tinggi terhadap anjuran pemerintah tentang protokol kesehatan. Adapun faktor yang mempengaruhinya adalah sikap dan pengetahuan antara lain memakai masker saat keluar dari rumah sebesar 95\%, yang selalu mencuci tangan dengan air mengalir/sabun setelah keluar dari rumah yaitu sebesar $98 \%$, selalu menjaga jarak saat sedang berada dikerumunan yaitu sebesar $94 \%$, sudah memakai masker dengan benar sebesar 97\%, yaitu masker sudah menutupi area mulut, hidung dan dagu.

Penyebab responden yang tidak menggunakan masker karena merasa tidak nyaman yaitu sebesar 37\% sedangkan yang tidak membawa hand sanitizer saat keluar dari rumah yaitu sebesar $41 \%$ dikarenakan jarak yang sangat dekat dari rumah, sehingga tidak perlu membawa hand sanitizer. Menurut (Saputro, Saputra, \& Prasetyo, 2020) responden yang tidak membawa hand sanitizer saat bepergian sebesar 56,9\% dan jika dibandingkan dari hasil penelitian sudah terdapat peningkatan sikap masyarakat yang membawa hand sanitizer saat keluar rumah/bepergian. Adapun jika dilihat dari faktor ekonomi dan persentase responden yang tidak menggunakan masker karena tidak memiliki uang hanya $7 \%$. Berdasarkan hal tersebut motivasi masyarakat untuk melindungi dirinya dari terpapar virus COVID-19 ini lebih tinggi dibandingkan dengan faktor ekonomi 
Analisis Faktor-Faktor yang Mempengaruhi Kesadaran dan Kepatuhan Masyarakat dalam Mematuhi Protokol Kesehatan di era Covid-19

karena dapat dilihat bahwa sebagian besar masyarakat mampu untuk membeli masker.

\section{Kesimpulan}

Kesadaran dan kepatuhan masyarakat dalam mematuhi protokol kesehatan di era COVID-19 adalah sangat baik dengan persentase masyarakat yang mengetahui anjuran dari pemerintah tentang protokol kesehatan sebesar 100\%, dan masyarakat yang sudah sadar dan mengerti mengenai protokol kesehatan sebesar 97\%. Sedangkan faktor-faktor yang mempengaruhi kesadaran dan kepatuhan masyarakat dalam mematuhi protokol kesehatan di era COVID-19 yaitu pengetahuan, persepsi, sikap, motivasi, dan komunikasi. 


\section{BIBLIOGRAFI}

Afrianti, Novi, \& Rahmiati, Cut. (2021a). Faktor-Faktor yang Mempengaruhi Kepatuhan Masyarakat terhadap Protokol Kesehatan Covid-19. Jurnal Ilmiah Permas: Jurnal Ilmiah STIKES Kendal, 11(1), 113-124.Google Scholar

Afrianti, Novi, \& Rahmiati, Cut. (2021b). FAktor-Faktor Yang Mempengaruhi Kepatuhan Masyarakat Terhadap Protokol Kesehatan Covid-19. Urnal Ilmiah Permas: Jurnal Ilmiah STIKES Kendal, 11(1), 113-124. Google Scholar

Albery, Ian P., \& Munafo, Marcus. (2011). Psikologi Kesehatan, Panduan Lengkap dan Komprehensif Bagi Studi Psikologi Kesehatan. Mitra Setia. Google Scholar

Aulia, Devy Lestari Nurul. (2021). Faktor-Faktor Yang Mempengaruhi Kepatuhan Ibu Hamil Dalam Mengkonsumsi Tablet Fe Di Kecamatan Meral Barat Kabupaten Karimun Tahun 2017. Zona Kebidanan: Program Studi Kebidanan Universitas Batam, 8(2). Google Scholar

Esposito, Susanna, Principi, Nicola, Leung, Chi Chi, \& Migliori, Giovanni Battista. (2020). Universal use of face masks for success against COVID-19: evidence and implications for prevention policies. European Respiratory Journal, 55(6). Google Scholar

Ginting, Tarianna, Kaban, Dhian Ladea, \& Ginting, Rapael. (2021). Kepatuhan pedagang pasar pagi dalam melaksanakan protokol kesehatan pencegahan COVID19. Jurnal Prima Medika Sains, 3(1). Google Scholar

K, Nafilah Sri Sagita. (2020). Awal Mula Wabah COVID-19 di Wuhan Diklaim Berasal dari Makanan Beku Impor Baca artikel detikHealth, "Awal Mula Wabah COVID19 di Wuhan Diklaim Berasal dari Makanan Beku Impor" selengkapnya https://health.detik.com/berita-detikhealth/d-5286363/awal-mula-wa. Detikhealth.

Kemendikbud. (2016). Kamus Besar Bahasa Indonesia (KBBI) daring.

Mudhar. (2017). Validitas dan Reliabilitas: Cara Mudah Analisis Secara Manual, Microsoft Exel dan SPSS. In M. S. Dra. Ayuni (Ed.), Kumpulan Jurnal, Prosiding, Buku, Poster, dan Karya Ilmiah UNIPA Surabaya. Surabaya: Adi Buana University Press.

Rosana, Ellya. (2014). Kepatuhan hukum sebagai wujud kesadaran hukum masyarakat. Jurnal Tapis: Jurnal Teropong Aspirasi Politik Islam, 10(1), 61-84. Google Scholar

Rukajat, Ajat. (2018). Pendekatan penelitian kuantitatif: quantitative research approach. Deepublish. Google Scholar

Saputro, Arnaz Anggoro, Saputra, Yudi Dwi, \& Prasetyo, Guntum Budi. (2020). Analisis Dampak Covid-19 Terhadap Kesadaran Masyarakat Dalam Penerapan 
Analisis Faktor-Faktor yang Mempengaruhi Kesadaran dan Kepatuhan Masyarakat dalam Mematuhi Protokol Kesehatan di era Covid-19

Protokol Kesehatan. Jurnal Porkes, 3(2), 81-92. Google Scholar

Soekanto, Soerjono, \& Pengantar, Sosiologi Suatu. (1982). Kesadaran Hukum dan Kepatuhan Hukum, edisi 1, Jakarta: CV. Rajawali. Google Scholar

Sulistyaningtyas, Tri, Jaelani, Jejen, \& Suryani, Yani. (2020). Power of knowledge and community social class above Covid-19 pandemic information on social media. Jurnal Komunikasi Ikatan Sarjana Komunikasi Indonesia, 5(1), 52-62. Google Scholar

\section{Copyright holder:}

Rizki Rahmah Fauzia, Retno Tresno Sundari, Zaenal Arifin (2021)

First publication right:

Syntax Literate: Jurnal Ilmiah Indonesia

This article is licensed under:

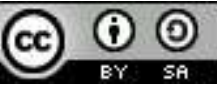

